\title{
Después de Auschwitz: la persistencia de la barbarie
}

\author{
RICARDO FORSTER
}

RESUMEN. En el artículo se intenta abordar la especificidad de Auschwitz persiguiendo los orígenes del antijudaísmo en las estructuras matriciales del primer cristianismo. El primer señalamiento a punta a una puesta en cuestión de la relación entre el Occidente cristiano y el judaísmo. A partir de allí se irá configurando la trama de la exclusión, primero, y del exterminio después. Luego se discute la equívoca posición de la ilustración, el conflicto insalvable entre la particularidad judía y la asimilación. Se llega hasta Heidegger, su compromiso con el nazismo y la solución final. En el último tramo se aborda la cuestión concentracionaria siguiendo algunos lineamientos elaborados por Giorgio Agamben donde se discuten las estrechas relaciones entre poder soberano, estado de excepción, biopolítica y lógica del exterminio destacando su terrible continuidad en la época actual.
Astract. The article broaches the specificity of Auschwitz tracking down the origins of antijudaism in the matricial structures of the first Christianity. The first aim is to bring into question the relationship between Western Christendom and Judaism. From then on, the plot of exclusion, first, then that of extermination, will be configured. Afterwards, the equivocal stand of Enlightment, the insurmountable conflict between Jewish particularity and assimilation will be discussed, reaching as far as Heidegger, his commitment to nazism and the final solution. In the last section, the concentrationary issue is tackled following some outlines elaborated by Giorgio Agamben, where the narrow relationships between sovereign power, state of exception, biopolitics and logic of the extermination are discussed highlighting their terrible continuity in the present age.

Después de Auschwitz. ¿Qué palabras utilizar para intentar describir la trama del infierno? ¿cómo volver a los textos ejemplares de la literatura allí donde el infierno era metáfora de una realidad imaginaria cuando, en Auschwitz, se ha vuelto manifestación de lo humanamente posible ${ }^{1}$ Preguntas iniciales,

${ }^{1}$ Edmónd Jabès ha descrito con palabras justas esta nueva configuración del infierno en la sociedad contemporánea: "Auschwitz es el infierno donde millones de seres humanos fueron los mártires inocentes de una monstruosa empresa de inferiorización, de desvalorización, de rebajamiento sistemático del hombre ante los ojos espantados de la muerte, tan degradada ella misma, que por primera vez conoció el asco (...). Por eso las llamas que se elevaban en el humo de 
simples marcas de una interrogación que no cesa de crecer en una época, la nuestra, que por diversos y extraños caminos vuelve a toparse con los relatos del horror, con la presencia, tan difícil de explicar, del mal absoluto asociado con el mal de la banalidad. Y decía que las palabras se opacan al intentar aproximarnos a aquello que fue y que significó la solución final porque frente a un acontecimiento de la naturaleza inédita del exterminio masivo de millones de seres humanos por parte de una maquinaria tecnológico-racional montada específicamente para desarrollar hasta sus últimas consecuencias esa finalidad propuesta por el nacionalsocialismo, el lenguaje queda enmudecido, las venerables categorías de análisis de las ciencias sociales parecen estallar en mil pedazos al intentar explicar el horror infernal y sus causas. Pero también el lenguaje corre otro peligro no menos grave: su puesta al servicio de una mentalidad massmediática, el pasaje de lo recluido en la memoria a la exposición prostibularia propia de los lenguajes de la industria del espectáculo asociada a otro fenómeno de época no menos significativo y peligroso: la apropiación política que el poder actual hace de aquel acontecimiento genocida como un modo de convertirlo en historia juzgada, cuya maldad incalificable ha quedado lejos de nuestro presente democrático y tolerante.

Auschwitz es mucho más que el nombre de un campo de exterminio, que el lugar en el que se focalizó la barbarie genocida del nazismo; Auschwitz concluye el itinerario maldito de un Occidente que hizo del "judío" el paradigma de lo abominable, alquimia de deicidio y contumacia, cómplices del demonio, usureros de los poderosos y apátridas preparados para la traición. El "judío" permaneció irreductible, un otro que amenazaba el dominio absoluto de la cristiandad; figura de una persistencia insoportable que insistía en sustraerse a la gramática homogeneizadora del logos occidental. Primero se trató del "gran chantaje" formulado por Pablo, los judíos como reponsables de la postergación sin tiempo de la definitiva culminación de una historia de pecado y sufrimiento; relapsos y negadores de la divinidad de Cristo que mientras persistieran en su rechazo seguirían provocando la presencia, entre los hombres, de la muerte y la penitencia ${ }^{2}$. El "judío" es quien mantiene como rehenes de su negación al conjunto de la humanidad. Trabajar para su conversión

los hornos crematorios no eran las del infierno de San Pablo. Las llamas de Auschwitz no purificaban el alma de los deportados. Las devolvían más livianas a la nada". (Edmónd Jabès, "El infierno de Dante”, Nombres, año III, Núm. 3, Córdoba, sept. de 1993, p. 132). Primo Levi también nos ofrece una imagen del infierno concentracionario: "Esto es el infierno. Hoy, en nuestro tiempo, el infierno debe ser así, una sala grande y vacía y nosotros cansados teniendo que estar de pie, y hay un grifo que gotea y el agua no se puede beber, y esperamos algo realmente terrible y no sucede nada y sigue sin suceder nada. ¿Cómo vamos a pensar? No se puede pensar ya, es como estar ya muertos. Algunos se sientan en el suelo. El tiempo transcurre gota a gota". (Primo Levi, Si esto es un hombre, Muchnik, Barcelona, 1995, p. 32). 


\section{significa quebrar ese chantaje insoportable ${ }^{3}$. Se trataba, para el dispositivo pau- lino, no de su eliminación física sino de su extraordinaria función en la economía de la salvación. Permanecer en "judío" significó un reto pero también una necesidad del propio cristianismo que, de ahí en más, tendrá a mano su chivo}

${ }^{2}$ En su Epístola a los Romanos Pablo despliega con especial intensidad la concepción del pueblo cristiano como rehen del "endurecimiento" judío y del rechazo de la condición mesiánica de Jesús. En 9: 6-13 el apostol destaca la sumisión de los hijos de Israel a los portadores del mensaje de Cristo: "El mayor servirá al menor, como dice la escritura: Amé a Jacob y odié a Esaú". La controvertida figura del hermano mayor que en la mayoría de los ejemplos bíblicos representa lo pervertido frente a la iluminante presencia del hermano menor (basta recordar el arquetipo originario señalado por Caín y Abel). Por eso no deja de ser oscura y poco feliz la sentencia papal de "mis hermanos mayores en la fe" que leída desde la tradición paulina adquiere un rasgo muy preciso. En 9: 30-33 Pablo destaca el "olvido de la fe" de Israel: "¿Qué diremos pues? Que los gentiles, que no buscaban la justicia, han hallado la justicia -la justicia de la fe- mientras Israel, buscando una ley de justicia, no llegó a cumplir la ley. ¿Por qué? Porque la buscaba no en la fe sino en las obras. Tropezaron contra la piedra de tropiezo, como dice la Escritura: He aquí que pongo en Sión piedra de tropiezo y roca de escándalo; más el que crea en él, no será confundido". Continúa la Epístola remarcando el endurecimiento de Israel, su profunda incomprensión del mensaje de Cristo (11: 5-10) culminando en ese texto que definió el lugar del judío en la economía de la salvación cristiana: "Pues no quiero que ignoréis, hermanos, este misterio, no sea que presumáis de sabios: el endurecimiento parcial que sobrevino a Israel, durará hasta que entre la totalidad de los gentiles, y así, todo Israel será salvo, como dice la Escritura: Vendrá de Sión el Libertador; alejará de Jacob las impiedades. Y esta será mi Alianza con ellos, cuando haya borrado sus pecados". (11: 25-27) [Biblia de Jerusalén, Bilbao, 1975, Nueva edición totalmente revisada y aumentada]. El cristianismo necesitó al "judío", el nacionalsocialismo, en la época de la secularización y la muerte de Dios, ya no necesitará la presencia del pueblo errante, su destino quedará sellado allí donde el crepúsculo de lo sagrado liberó a la conciencia europea, particularmente la alemana, de los destellos de la teología paulina que, como lo hemos señalado, les otorgó a los hijos de Israel un lugar, terrible y precario pero lugar al fin, en la economía de la salvación.

${ }^{3}$ George Steiner ha ahondado, en varios de sus libros, en esta cuestión crucial: "Si me fuera concedido volver a nacer en otro mundo, elegiría la vida de un historiador o un pensador del mundo mediterráneo en los años 30 a 300 después de C., pues son años en los que se produjeron la mezcla y la trágica separación entre Atenas y Jerusalén, y de los que puede decirse que tuvieron, como ineluctable consecuencia, los campos de la muerte. ¿Cómo podemos tomar en serio los capítulos 9 y 12 de la epístola a los Romanos, donde Pablo afirma que, con su renuncia al Mesías, los judíos toman como rehén, hasta el final de los tiempos, a la humanidad entera, algo que se convierte en su condición histórica? Claudel hizo también una reflexión sobre ese tema. El hombre no puede evitar la rueda de la fortuna de la Historia mientras el pueblo judío se niegue a entrar en la ecclesia. Esta fatal e inteligente apuesta anuncia que, un día u otro, se producirán las matanzas". (George Steiner en diálogo con Ramin Jahanbegloo, Anaya \& Muchnik, Madrid, 1994, pp. 122-123). En otro libro donde se recoge su diálogo con Pierre Boutang, pensador formado en la tradición de la derecha francesa, Steiner vuelve sobre esta cuestión:

Boutang: “...todo el mundo sabe que son los reyes y los papas y la Iglesia quienes han protegido a los judíos contra los otros. Que el antisemitismo criminal es algo popular e incluso populachero, que no tiene sentido. Pero está absolutamente claro que esta Sinagoga ciega debe según las profecías convertirse, transformarse, reconocer que se equivocó... al no reconocer". (Pierre Boutang y George Steiner, Diálogos sobre el mito de Antígonas y el sacrificio de Abraham, ediciones Destino, Barcelona, 1994, p. 98) Boutang es terriblemente claro en su ambiguedad: la palabra Sinagoga arrastra en su boca siglos de afrenta, de envilecimiento, de desprecio. La Sinagoga se ha equivocado al rechazar al verdadero Mesías; los judíos erran por la historia porque son prisioneros de su 
emisario, el sujeto perpetuo del desprecio, el errante por definición que ha perdido su hogar y que vaga por el mundo sin ser de ninguna parte. La figura del apátrida, del desterritorializado alcanzará un lugar prominente en la época del estado-nación, pero su sombra ya se extiende desde el via crucis de Jesús.

“Lyotard escribe 'los judíos' -Héctor Schmucler está haciendo referencia al libro de Jean-François Lyotard, Heidegger y los "judios"- en un plural indeterminado, para subrayar que no habla de lo judío como hecho político, ni religioso, ni filosófico. ¿Pero queda realmente algo de lo judío si se deja a un lado (se olvida) que su único y hasta ahora indoblegable lugar de pertenencia es la memoria y que esa memoria no hace otra cosa que repetir el fundamento religioso de su existencia? La memoria judía se enraíza: la Torá, el Talmud y los inacabables comentarios que les dan incesante vida. Lo judío tiene un punto de partida irreductible: el pacto sin precedentes impuesto por Dios a los hombres. Desde aquel entonces todo lo que se debe hacer es no olvidarlo:

ceguera. El antisemitismo es cosa del populacho. Los príncipes de la verdad, los dueños del poder, siempre los han protegido... Pero reconozcamos que su intransigencia, que su desconocimiento de Cristo, constituye el error de los errores. De ahí partimos y lo demás carece de importancia. Boutang expresa un profundo y radical antijudaísmo. Su rechazo es doctrinario, no es "populachero". En este sentido, y sólo en éste, Boutang no es un nazi.

Steiner: “...tenga el valor, por Dios, de decir que para ustedes la desaparición del judío sería finalmente...

Boutang: "Lo contrario de mi pensamiento.

Steiner: “...la validación de lo que dice a la vez la Epístola de los Romanos...

Boutang: "No, la Epístola a los Romanos no dice eso!" (p. 120)

Steiner coloca a Boutang delante de un imposible; que un católico contrarreformista, identificado con el pensamiento de Mourras, acepte que en la Epístola a los Romanos estaba explícitamente planteada la necesidad de la "desaparición del judío", pero no en términos de conversión, de pacífica aceptación del mensaje de los evangelios, sino como figura final del horno crematorio. La formulación de Steiner es durísima: San Pablo inaugura la época de la persecución del judío y la terrible resolución nazi sería el punto de cierre de esa búsqueda continua, por parte del cristianismo, de hacer desaparecer al judío. Boutang habla de "conversión", pero ¿qué ocurre si el destinado a la conversión la rechaza? Es interesante, y escalofriante, que Boutang frente a lo intolerable e inaudito de Auschwitz lo compare, pensando en el problema del mal, con el sufrimiento de un niño. La lógica del argumento se entiende: el mal nace allí donde emerge el sufrimiento en cualquiera de sus formas; pero más allá de la lógica impecable de la argumentación está la actitud ante la Shoah, su reducción, vía la comparación de todo sufrimiento, a casi una anécdota más en el largo itinerario del mal. De esta manera, Boutang se desentiende rápidamente de la cuestión, su conciencia se alivia y cree poner en su justo lugar el dolor judío, que no debería ser mayor que el dolor de un niño, ni merece serlo! La Shoah prácticamente desaparece de escena; suena casi como una exageración... judía. En diferentes momentos de su obra George Steiner ha vuelto sobre esta cuestión crucial, es particularmente significativo y esclarecedor su ensayo “A través de ese espejo, en enigma” publicado en Pasión intacta, Siruela, Madrid, 1997. 
la memoria como deber inapelable y como condición de existencia. La persecución a los judíos, desde siempre, tuvo como objetivo destruir la memoria: en la historia de los libros, tal vez ninguno haya sido tan condenado como el Talmud. Es probable que las cosas sean a la inversa de lo que imagina Lyotard y Europa haya sabido, siempre, qué hacer: eliminarlos secando sus raíces, la memoria ${ }^{4}$. El nazismo tuvo el gesto más audaz y desesperado. Convencido de que era inútil el esfuerzo que llevaba dos mil años y creyendo que la memoria judía es indestructible, buscó la solución final: eliminar a sus portadores. Ninguna eternidad es posible si no existen seres que piensen en

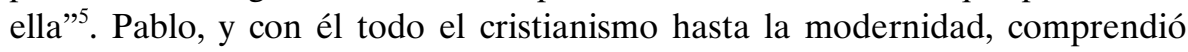
que ese sujeto que permanecía fiel a la memoria, que habitaba un libro como si fuera una patria y lo volvía infinito y abierto, representaba el peligro, la presencia de una otredad que el logos greco-cristiano no podía ni debía tolerar. Fuera de la historia, ajeno al mensaje salvador de Jesús, testigo de lo intolerable por inasimilable, el "judío" atravesó la historia europea siendo el portador de una marca despreciable cuyo destino no podía ser otro que el de la asimilación o la desaparición. Quemar el Talmud fue el comienzo de una historia que culminó en la gran hecatombe de los cuerpos judíos en la gigantesca hoguera que los nazis construyeron como corolario del insostenible lugar de esa figura huidiza y extranjera en el seno de una civilización fundada en lo igual a sí mismo, es decir, en un logos doblegador incesante de toda diferencia. Auschwitz, es posible decirlo así, culminó lo que desde un comienzo habitó la conciencia cristiana allí donde el "judío" fue definido como el responsable de la ejecución de Cristo y el causante de la postergación del fin de la historia y su corolario salvífico.

El otro, el extranjero, el judío describió su periplo por la geografía de Occidente recorriendo las tierras marginales, permaneciendo en el umbral a la espera de un tiempo continuamente postergado. Excluido pero instalado a tiro del poder, el judío constituyó en la Europa medieval ese personaje capaz de asumir en su figura demonizada todo el odio del pueblo; como si en el martirio al que fueron sometidos por turbas fanatizadas dirigidas por frailes y curas, se hubiera reproducido, en su forma contraria, el sufrimiento de Cristo. Estaban allí como símbolo del rechazo y la negación, eran aquellos que condenaban a todos los fieles a una espera interminable mientras insistían con

${ }^{4}$ En su libro Lyotard plantea esta cuestión del siguiente modo: "Lo más real de los judíos reales es que Europa, por lo menos, no sabe qué hacer con ellos: cristiana, exige su conversión; monárquica, los expulsa; republicana, los integra; nazi, los extermina. 'Los judíos' son el objeto del no ha lugar por el que los judíos, en particular, son golpeados realmente". J-F Lyotard, Heidegger y "Los Judios", ed. La marca, Buenos Aires, 1996, p. 17

5 Héctor Schmucler, "Formas del olvido", Confines, Núm. 1, 1995. 
su absurda fidelidad a una ley perimida. Quemar sus libros mefistofélicos, masacrarlos en medio del aquelarre de cruzados y miserables, incendiarlos junto a sus sinagogas, violar a sus mujeres y ensartar a sus niños en las espadas de los soldados de Cristo que se preparaban para liberar el Santo Sepulcro, fueron algunas de las prácticas cotidianas de la Europa medieval mientras la Iglesia, después de haber generado las condiciones para su repudio y demonización, intentaba tibiamente proteger unas vidas que debían participar en la economía de la salvación. Mientras que los obispos, cuidadosos intérpretes de las Escrituras, elaboraban alambicados discursos proteccionistas, desde los púlpitos de miles de iglesias, en el altar de innumerables conventos, curas desprovistos de cualquier sutileza teológica llamaban a las cosas por su nombre: los judíos eran los eternos asesinos del Señor y debían pagar su inmunda culpa bajo el peso de la espada o aceptar, en el arrepentimiento y la contrición, el camino señalado por el calvario de Jesús.

Hay ciertas frases cuyo destino en la historia contradice profundamente lo que quisieron decir sus autores. Frases que dibujan un itinerario que las aleja de su sentido original. En definitiva, no hay texto que pueda permanecer atado a un sentido pero hay algunos que se sustraen más dramáticamente a las intenciones de sus autores. Herder escribió una de esas frases. Para él los judíos eran un pueblo "extranjero" en Europa, un pueblo que provenía del Asia. Claro que en Herder esta condición "extranjera” distaba de ser un reproche o de fundar una actitud de rechazo; se trataba, por el contrario, de un reconocimiento y hasta de un gesto de admiración. Los judíos alimentaban a Europa con su originalidad, su condición "extranjera" se volvía un beneficio. Y sin embargo Europa no leyó con ese espíritu la frase de Herder, no quiso reconocer en ella el punto de encuentro de dos culturas ni la deuda contraída con el judaísmo. El judío se volvió literalmente "extranjero" en Europa, es decir, un otro negado y rechazado, un errante sin patria ni raíces que venía a contaminar el suelo cristiano. La palabra "extranjero" adquirió su connotación más vulgar y terrible: la del temor ante el diferente, la del que siente rechazo por el otro. Lejos quedaba el significado bíblico del "extranjero" como aquel al que hay que ofrecerle albergue y al que hay que cuidar; sentido que todavía aparece en Herder pero que se vuelve inactual en su interpretación posterior. El judío se convirtió, pese a Herder, en el "extranjero" por esencia, en un otro que lejos de aportar a la conformación plural de una cultura se volvía amenaza. Distante de la idea de hospitalidad propia de la tradición judía (la universalidad cristiana no es hospitalaria con el "otro", busca su incorporación y no efectúa el acto hospitalario del reconocimiento en la diferencia), Europa se volvió autorreferencial haciendo del rechazo a lo ajeno de sí misma una práctica civilizatoria que ya no se detendría hasta alcanzar su expresión más 
extrema y bárbara con la Shoah. Una frase escrita para darle al otro un lugar sufre, pese a su autor, los trágicos designios de la historia hasta volverla su perfecto contrario. Esto ha llevado a los propios judíos a tener que clausurar cualquier referencia a su condición genuina de "extranjeros" para volverse "nacionales": judeo-alemanes, judeo-franceses, judeo-norteamericanos, judeo-argentinos y hasta judeo-iraelíes, sin que ese pasaje haya impedido la continuidad del rechazo y, en pleno siglo XX, la tragedia del judaísmo europeo. Ya no hay lugar para lo simplemente judío, para aquello que representaba, según Herder, lo creativo y original, su presencia como "extranjeros" que son capaces de preñar otra cultura con su propio genio. Claro que Herder concluirá con la idea de que esa historia debe confluir, y negarse, en la nueva historia del presente. Se trata, tal vez, de que Europa vio desde siempre al judío como el portador de una amenaza, como aquel otro que se internaba en su seno sosteniendo una visión del mundo irreductible al universalismo de la razón greco-cristiano-ilustrada ${ }^{6}$. Esa irreductibilidad, esa permanencia en la diferencia, condujo a la única solución posible después de haber fracaso la alternativa asimilacionista: dejar que los nazis recorrieran el camino sin retorno, para el judaísmo europeo, de la Solución Final. Ese no hacer nada ante la gigantesca hoguera que se levantó en el corazón de Europa sigue marcando a fuego el fracaso, en toda la línea, de la racionalidad occidental y de sus promesas liberadoras. La destrucción de los judíos en el infierno concentracionario significó, también, el doblegamiento de la civilización occidental a la lógica del mal absoluto que no eludió sus raíces logocéntricas sino que las llevó a su extremo. Ese lugar imposible del "extranjero", esa incapacidad de Europa de ser "hospitalaria" ha calado hondo en el devenir histórico del antisemitismo, entendiéndolo, desde esta perspectiva, como el síntoma de una cultura imperial, universalista y reductora de toda diferencia. De la écumene cristiana soñada por Pablo, pasando por la Iglesia medieval y el universalismo ilustrado, lo que quedaba en el fondo del túnel no era la aceptación del otro, el dejar que el extranjero habitara libremente la geografía de Occidente, no, lo que

${ }^{6}$ Reyes Mate ha señalado con particular énfasis la tendencia de la tradición cristiana, asumida luego por la ilustrada, de volver literalmente intolerable para su universalidad el lugar descentrado del judío: "La racionalidad occidental lleva el sello cristiano. Y por mucha secularización que se le eche, el sello sigue denotando el origen. Esa secularización, sin embargo, es tan profunda que la referencia al origen puede pasar inadvertida a cualquier post-cristiano, es decir, a cualquier hombre moderno. Pero no al judío". Reyes Mate destaca la esencial discrepancia entre lo que él denomina, en el caso de la tradición cristiano-ilustrada, una "universalidad particular", devoradora de cualquier diferencia, de aquella otra que construida desde la marginalidad es la que efectivamente conocen los judíos, una "universalidad universal", aquella que puede desplegarse por el mundo sin necesidad de tener que someter a sus propios presupuestos todas aquellas particularidades que habitan por fuera de sí misma. Véase de Reyes Mate, Memoria de Occidente. Actualidad de pensadores judíos olvidados, Anthropos, Barcelona, 1997, p. 16. 
esperaba para dar su zarpazo definitivo era Auschwitz, que no sólo representa el fin del judaísmo europeo sino que también supone la quiebra moral de toda una civilización. Quizás, en este sentido, la especificidad de la Shoah esté ligada directamente con este no retorno de la conciencia europea, es decir, de la razón occidental, a sus promesas de libertad e integración, para acabar de poner al descubierto su fondo ominoso y destructivo, su incapacidad para establecer una relación con el otro que no se resuelva o en sometimiento o en exterminio. Por eso le sigue resultando tan difícil a Europa abordar en toda su complejidad y hondura lo que ha significado Auschwitz; por eso ha preferido hacer del nacionalsocialismo un accidente horroroso e inesperado, una suerte de extraña enfermedad alucinatoria que atravesó la vida alemana durante dos décadas, volviéndolo inexplicable en términos de su propia travesía civilizatoria, puerto de llegada de dos milenios de construcción del "judío" como ese otro insoportable e intolerable, hasta reducir esa andadura sostenida en violencias verbales y violencias físicas a un enloquecimiento repentino del pueblo de poetas y filósofos que, un día aciago, se dejó tentar por el Diablo y ganado para su causa malvada acabó por destruir a ese extranjero eternamente indeseable.

3.

Descuidar, a la hora de intentar penetrar en los horrores de la Shoah, el largo proceso de construcción del imaginario antisemita en el seno de la cultura occidental (que en la tradición inaugurada por Pablo y perpetuada por el cristianismo medieval es básicamente antijudía), tratando exclusivamente de limitar la lógica atroz del exterminio al irracionalismo hitleriano, es perder de vista las condiciones que hicieron posible que pudiera destrozarse al judaísmo europeo sin que prácticamente nadie se haya opuesto. No deja de ser significativo y ejemplar, por lo que ha implicado para la propia tradición filosófica, el silencio de Heidegger ante el exterminio de los judíos a manos de aquellos que instalaron su concepción homicida en el corazón de Alemania ${ }^{7}$. J-F. Lyotard ha intentado indagar en este silencio del autor de Ser y Tiempo: "Y que 'concluía' -Philippe Lacoue-Labarthe- que el crimen de esta política -se está refiriendo a Hei-

${ }^{7}$ Para profundizar en una suerte de comparación entre la filosofía de Heidegger y el pensamiento judío, particularmente el de Rosenzweig y Benjamin, resulta útil el libro de Reyes Mate, Heidegger y el judaísmo, Anthropos, Barcelona, 1998. Para indagar la posible postura de Heidegger ante el exterminio y la terrible lógica de la Solución final, es muy sugerente el libro de J.L. Nancy, La experiencia de la libertad, Paidós, Barcelona, 1996, capítulo 12, y los libros de Philippe Lacoue-Labarthe, La poésie comme expérience, Bourgois, París, 1986, p. 167, y La fiction du politique, Bourgois, París, 1988. 
degger- reside no tanto en el compromiso nacionalsocialista del rector de Friburgo como en el silencio observado hasta el final por el pensador de Todtnauberg sobre el exterminio de los judíos (...). De ahí la paradoja, y hasta el escándalo: cómo pudo este pensamiento (el de Heidegger) absolutamente dedicado a recordar lo que hay de olvido (del ser) en todo pensamiento, en todo arte, en toda 'representación' del mundo, ignorar el pensamiento de 'los judíos', que en cierto sentido no piensa, no intenta pensar, más que eso; olvidarlo e ignorarlo hasta el punto de que calla hasta el final, que niega, la tentativa horripilante (e inane) de exterminar, de hacer olvidar para siempre lo que en Europa recuerda, desde el comienzo, que "hay' Olvidado". "Olvido" de aquellos que han tejido su marcha por la historia con los hilos de la memoria; de aquellos que no pudieron sustraerse al mandato, a la Ley, del recuerdo. Heidegger, filósofo que nos señala el "olvido" de Occidente y de su metafísica, no tiene una sola palabra para nombrar a los olvidados de esa historia de sustracciones (sería bueno aclarar que el despliegue histórico de las políticas del olvido concluyó, no azarosamente, con el exterminio judío a manos de los nazis; como si en ese gesto milenario -cristiano, monárquico, republicano o nazi- ya hubiera estado, desde el principio, escrito el destino de los olvidados: el exterminio). Heidegger calla. He ahí su complicidad. Lo demás, y estoy de acuerdo con Lacoue-Labarthe y con Lyotard, es menos relevante y hasta puede ser atribuido a un error político o a la estupidez del filósofo; lo que no puede obviarse es su silencio posterior. En ese callar se manifiesta lo impronunciable del genocidio, la presencia de una obturación que hace resistencia a la voz exterminada y de la que Heidegger no puede, no quiere ni sabe decir absolutamente nada. En su silencio habla lo imposible de la memoria y pende como una lápida ilevantable allí donde lo atroz no es escuchado ni reconocido. ¿Cómo sostener el filosofar después de que lo inaceptable fue aceptado y silenciado? ¿cómo seguir trabajando con el lenguaje cuando las palabras quedaron comprometidas con el mal absoluto? ies acaso el silencio de Heidegger una astucia del mal? Paul Celan peregrinó hasta Todtnauberg para escuchar una palabra, una sola palabra del filósofo y regresó cargando un silencio ominoso, un no decir que, para el poeta, se volvió abyección. ¿Qué dice el silencio de Heidegger? Para Celan es prueba dolorosa de la iniquidad. ¿Y para nosotros? En la época de las omisiones y de la insustancialidad del lenguaje parecería que exigirle al filósofo un descargo, asumir una responsabilidad, fuera un acto imposible y absurdo. El que esté libre de pecados que arroje la primera piedra se dice a nuestro alrededor y, ante tamaña exigencia, sólo queda la púdica retirada; ya nada se puede decir, las palabras son cáscaras

${ }^{8}$ J-F. Lyotard, op. cit., p. 18 
de un vacío. ¿Para qué entonces la filosofía si ella no es capaz de enfrentarse a lo terrible de nosotros mismos? ¿Qué extraño sortilegio pudo hacer de Heidegger, al mismo tiempo, uno de los pensadores imprescindibles de nuestro siglo, un verdadero espíritu innovador, y aquél que con su silencio ominoso se desentendió del sordo pedido del poeta? ¿acaso la barbarie del siglo XX incluya, como mecanismo extremo del mal, la proximidad injuriante del filósofo del olvido del ser y el silenciamiento cómplice del exterminio masivo de seres humanos? ¿ése es el camino de una interrogación radical? Lyotard se detiene, a través de una aguda reflexión sobre Freud y "lo olvidado", en ese punto que diferencia a la verdadera historia (en tanto que anamnesis) del historicismo; una historia que "no olvida que el olvido no es una claudicación de la memoria, sino de lo inmemorial aún y siempre 'presente', nunca aquí-ahora, siempre escindido en el tiempo de la conciencia, crónica, entre un demasiado temprano y un demasiado tarde" ". Heidegger "olvida" como un gesto de escisión con un acontecer que se le vuelve señal de lo ominoso; su "olvido" no funda ninguna historia verdadera sino que sostiene una obturación, clausura la palabra que pueda intentar pronunciar la responsabilidad ante el mal. No se trata de una represión primaria, de un "primer golpe asestado al aparato, que no lo siente", sino de una astucia de lo infame, de un silenciamiento cómplice. Lo no soportable, en Heidegger, se vuelve olvido, sustracción de la verdad que se opone a la historia verdadera. Porque el filósofo sabe que ese "no ha lugar" de la palabra que decide no pronunciarse respecto a la Shoah funda una interpretación y un modo muy preciso de hacer historia; hay allí una responsabilidad que no puede ser desconocida por Heidegger: la de ofrecerles a las víctimas como destino final la nada del lenguaje, el hueco de la memoria. Celan, que amaba las "sendas perdidas" heideggerianas, fue hacia el filósofo para escuchar una palabra que le devolviera a los olvidados un trazo de su memoria. Sólo recogió el silencio ${ }^{10}$. Quizás en el silencio del filósofo podamos descubrir lo imposible de ser dicho por una tradición que, ante sus propios delirios asesinos, prefiere escudarse en el enmudecimiento. Pero tal vez, lo propio y específico de Auschwitz, sea aquello que le impide a Heidegger pronunciar una palabra ante Paul Celan. ¿Qué decir y cómo decirlo? Al hundir su puñal en el pecho

9 J-F. Lyotard, op. cit., p. 32

10 Dejemos que el poeta diga su palabra ante este fatal desencuentro con el filósofo:

“Árnica, alegría de los ojos, el/trago del pozo con el/ dado de estrellas encima,/// en la/ cabaña/// escrita/ en el libro/ -iqué nombres anotó/ antes del mío?-/ en este libro/ la línea de/ una esperanza, hoy,/ en una palabra que adviene/ de alguien que piensa, en el corazón,/// brañas del bosque, sin allanar,/ satirión y satirión, en solitario,/// crudeza, más tarde, de camino,/ evídente,/// el que nos conduce, el hombre,/ que lo oye también,/// las sendas/ de garrotes a medio/ pisar, en la turbera alta,/// mojado/ mucho". Paul Celan, "Todtnauberg”, Obras completas, traducción de José Luis Reina Palazón, Trotta, Madrid, 1999, pp. 321-322. 
del judaísmo europeo, lo que se muere junto a él es el derecho de la propia tradición filosófica a continuar su camino especulativo sin hacerse cargo del mal irradiado desde su más profunda esencia. Esto, suponemos, Heidegger lo sabía. Nunca como antes de la Solución final toda la tradición metafísica de Occidente había alcanzado tal grado de compromiso, tal contaminación con el ejercicio de la destrucción total implementado por el nazismo, inclusive allí donde se mantuvo apartada y en supuesta oposición. Simplemente es impensable que la racionalidad occidental haya podido salir indemne de la tragedia judía.

Auschwitz enfrentó al pensamiento con su propio indignidad, desnudó la barbarie que se agazapaba en el despliegue civilizatorio de Occidente. Tal vez por eso la desolada reflexión de Theodor Adorno siga siendo absolutamente actual y pertinente: "Auschwitz demostró irrefutablemente el fracaso de la cultura. El hecho de que Auschwitz haya podido ocurrir en medio de toda una tradición filosófica, artística y científico-ilustradora encierra más contenido que el de ella, el espíritu, no llegara a prender en los hombres y cambiarlos. En esos santuarios del espíritu, en la pretensión enfática de su autarquía es precisamente donde radica la mentira. Toda la cultura después de Auschwitz, junto con la crítica contra ella, es basura. Al restaurarse después de lo que dejó ocurrir sin resistencia en su casa, se ha convertido por completo en la ideología que era en potencia desde que, en oposición con la existencia material se arrogó el derecho de insuflarle la luz; una luz que precisamente el aislamiento del espíritu se había reservado para sí quitándosela al trabajo corporal. Quien defiende la conservación de la cultura, radicalmente culpable y gastada, se convierte en cómplice; quien la rehúsa fomenta inmediatamente la barbarie que la cultura reveló ser. Ni siquiera el silencio (Adorno está anticipando aquí el silencio de Heidegger) libera de ese círculo; lo único que hace es racionalizar la propia incapacidad subjetiva con la situación de la verdad objetiva, degradando de nuevo a ésta a una mentira" ". Una cultura quebrada en su más profunda estructura es lo que Auschwitz ha dejado como herencia y lo que lo vuelve, independientemente de cualquier pretensión de originalidad, una experiencia única en la travesía histórica de Occidente, suerte de marca imborrable que, sin embargo, nos abre hacia una región de nuestro ser que preferimos olvidar. Lo despiadado del análisis de Adorno, su escritura condenatoria, implica que el universo concentracionario imaginado e implementado por los nazis contamina al conjunto de la cultura. Como si la extraordinaria promesa ilustrada, aquella que soñaba con una sociedad definitivamente liberada de oscuras y bárbaras ataduras, hubiera encontrado en la lógica del exter-

11 Th.W. Adorno, Dialéctica negativa, Taurus, Madrid, 1992, trad. de J.M. Ripalda, p. 367. 
minio masivo de seres humanos su más absoluto mentis. J-L. Nancy lo ha dicho de un modo complementario al sostener que "Auschwitz ha significado la muerte del nacimiento y de la muerte, su conversión en abstracción infinita, la negación de la existencia; y es quizás ante todo eso lo que la 'cultura' ha hecho posible"12. La cultura moderna fundada en los principios de la libertad y la autonomía de los individuos, paridora supuestamente de una sociedad abierta hacia procesos de reforma capaces de doblegar la violencia inscripta en lo humano hasta literalmente forjar un nuevo tipo de humanidad liberada de su propio salvajismo y creadora de una verdadera convivencia democrática, ha "hecho posible", como lo destacan crudamente Adorno y Nancy, el advenimiento de una civilización en la que nacimiento y muerte se hayan vuelto una "abstracción infinita". Auschwitz es el nombre de ese fracaso en toda la línea de las promesas de la modernidad ilustrada, su terrible sombra compromete el futuro de nuestros pasos en la medida en que no seamos capaces de interrogar/nos respecto a lo que "queda de Auschwitz" en nosotros ${ }^{13}$.

\section{4.}

Intentar recortar lo específico de Auschwitz no significa aislarlo de aquellas otras formas de la destructividad que han venido asolando la vida humana; se trata, por el contrario, de indagar por su particularidad como un modo de encontrar, si ello es posible, sus correspondencias, sus cruces, lo que a partir del exterminio nazi se vuelve un ejemplo mayúsculo de ciertos proyectos biopolíticos que siguen habitando la escena de nuestra época; pero es también recorrer hacia atrás, hacia el fondo de la cultura occidental, los mecanismos religiosos, metafísicos y políticos que convirtieron al "judío" en el excluido por excelencia, el límite desde el cual se forjaron los derroteros de nuestra civilización hasta alcanzar su cota máxima en los campos de la muerte, verdadera bisagra en nuestra travesía por el tiempo y en nuestra condición humana.

\footnotetext{
12 J-L. Nancy, op. cit., p. 138.

13 “...pensamos que hay una secreta connivencia, más acá de diferencias fundamentales, entre los campos y todo aquello que, por explotación, por abandono o por tortura, presenta en nuestra época lo que se podría juntar bajo los títulos, a la vez materiales y simbólicos, del encarnizamiento, de la desencarnadura, y de la carnicería (...). Habría que volver a trazar la circulación entre la brutalidad de la acumulación primitiva del capital puesta a la luz del día, la del 'malestar en la civilización', y la de la barbarie civilizada y tecnificada”. (J-L. Nancy, op. cit., p. 139, nota 5) Es de impostergable lectura, en relación a lo que sostiene Nancy, la última obra de Giorgio Agamben, Homo Sacer. El poder soberano y la nuda vida y su último tomo, Lo que queda de Auschwitz. El archivo y el testigo. Homo Sacer III, ambos en Pre-textos, Valencia, 1998 y 2000, traducidos por Antonio Gimeno. Volveré, de todos modos, sobre algunos de los señalamientos de Agamben en este mismo ensayo.
} 
En este sentido, resulta iluminante y polémico el análisis que desarrolla Giorgio Agamben alrededor del concepto de Homo sacer y que nos gustaría presentar como un complemento necesario para pensar más profundamente la figura del exterminio.

"La nuda vida tiene, en la política occidental, el singular privilegio de ser aquello sobre cuya exclusión se funda la ciudad de los hombres”. Agamben extrema la posición llevando a los orígenes de la Polis el advenimiento de una lógica de la exclusión sobre la que se montará el universo significativo de la política tal como la ha venido entendiendo Occidente más allá de sus giros epocales. Estamos, según el filósofo italiano, en el seno de una continuidad histórica, de ahí que sostendrá que la pareja categorial fundamental de la política occidental no es la de amigo-enemigo (tan cara a Carl Schmitt), sino la de la nuda vida-existencia política, zóê-bíos, exclusión-inclusión. Hay política porque el hombre es el ser vivo que, en el lenguaje, separa la propia nuda vida y la opone a sí mismo manteniéndose, al mismo tiempo, en relación con ella desde la lógica de una inclusión exclusiva. Agamben dirá, entonces, que se opera un doble movimiento que funda la política occidental: de un lado el advenimiento material de la nuda vida, aquel individuo eliminable, puro desecho sin significación, y, por el otro lado, la construcción, en tanto fenómeno del lenguaje, de la exclusión. Por eso afirmará que el protagonista de su libro es la nuda vida, es decir la vida a quien cualquiera puede dar muerte pero que es a la vez insacrificable del homo sacer $^{14}$. El hallazgo de Agamben es notable ya que a través de esta oscura figura del derecho romano arcaico logra hacer pensable el mecanismo que constituye la figura del poder soberano como fuente de exterminio sin contradecir, y éste es el escándalo que subyace a la política de Occidente, al propio derecho. Agamben ha captado ese momento obturado por el logos en el que el humano es depojado de su humanidad, nulificada su existencia y, por tanto, utilizable y eliminable según las necesidades políticas del soberano (el Estado en el sentido moderno del término). Al introducir el bíos en la Polis, el Estado moderno crea las condiciones, aparentemente contradictorias, tanto para el cuidado de la vida (políticas sanitarias) como

${ }^{14}$ Homo sacer es una oscura figura del derecho romano arcaico, en que la vida humana se incluye en el orden jurídico únicamente bajo la forma de su exclusión (es decir de la posibilidad absoluta de que cualquiera le mate sin ser responsable jurídico ni penable por dicha acción aniquiladora). La entera reflexión agambediana está montada sobre esta sorprendente figura jurídica que le permite establecer un hilo conductor que atraviesa la historia de Occidente y define su universo político. Por supuesto que a lo largo del tiempo, y de los clivajes históricos, esa figura ha ido cobrando distintas expresiones hasta casi desaparecer su matriz originaria. El mérito de Agamben es haber recuperado, en nuestros días, la presencia ominosa pero esencial del Homo sacer, del puro sujeto de la exclusión que, paradójicamente, funda la posibilidad de la ciudad de los hombres. 
para su simple eliminación. En la sociedad contemporánea, a diferencia de la antigua, la cuantificación de la muerte devendrá en su negación, es decir, en su desacralización (incluimos aquí a las diversas muertes violentas -a través de guerras, desplazamientos poblacionales, hambrunas nacidas de políticas encubiertas por parte del poder, exterminios concentracionarios- y también, aunque bajo otro registro ético, las muertes médico-hospitalarias). Presencia masiva, continua, pero invisibilizada, la muerte domina el horizonte de existencia de las sociedades contemporáneas en una medida jamás antes conocida. Su dominio es correlativo a su desimbolización, a su reducción numérica. La estadística ha reemplazado la antigua presencia sagrada de la muerte.

"Cuando sus fronteras se desvanecen y se hacen indeterminadas, la nuda vida que allí habitaba queda liberada en la ciudad y pasa a ser a la vez el sujeto y el objeto del ordenamiento político y de sus conflictos, el lugar único tanto de la organización del poder estatal como de la emancipación de él"15. La política no se funda, como lo ha venido sosteniendo Occidente desde sus inicios, en el gesto de la libertad, en el control ejercido sobre el poder despótico y en la emergencia de una palabra pública emanada de los ciudadanos, sino en la presencia-ausencia de la nuda vida en la ciudad; es a partir de ella que se articula el ordenamiento político. La exclusión-inclusiva es la clave que nos permite desarticular la maquinaria del poder soberano, es la llave maestra que abre la puerta del brumoso comienzo en el que se trazaron las líneas de la vida y de la muerte. Pero Agamben es aún más radical en su reflexión: todos los súbditos son potencialmente nuda vida; la amenaza continua del poder soberano, el verdadero secreto de su dominio, es esa potencialidad a través de la cual todo hombre es pausible de ser matado por el Estado ${ }^{16}$. "Nuestra política no conoce hoy ningún otro valor (y, en consecuencia, ningún otro disvalor) que la vida, y hasta que las contradicciones que ello implica no se resuelvan, nazismo y fascismo, que habían hecho de la decisión sobre

${ }^{15}$ Giorgio Agamben, Homo Sacer. El poder soberano y la nuda vida, Pre-textos, Valencia, 1998, trad. de Antonio Gimeno, p. 19.

${ }^{16}$ Vale la pena recordar, para todos aquellos que se horrorizan ante esta afirmación y declaran su desacuerdo, que los estados-nación condujeron, a lo largo de los últimos siglos, a grandes porciones de sus poblaciones hacia guerras en las que fueron exterminados millones de seres humanos convertidos en Homo sacer, es decir, en vida matable pero insacrificable en aras de políticas estatales que actuaron en el marco de la legalidad jurídica y del estado de derecho (io acaso los soldados norteamericanos que fueron a morir al Vietnam no fueron movilizados respetando rigurosamente la legislación y el estado de derecho? ¿y las tropas francesas que se internaron profundamente en la Rusia zarista bajo el mando napoleónico no fueron llamadas por la patria y de acuerdo al derecho?). No hay que confundirse, el Estado no mata sólo a través de políticas genocidas (lo ha venido haciendo desde su propia instauración), lo hace también apelando a la ley. Otras tantas cosas podrían decirse de la impunidad hospitalaria hasta bien entrado el siglo XX. 
la nuda vida el criterio político supremo, seguirán siendo desgraciadamente actuales" ${ }^{\prime 17}$. Si es la vida el centro de la política, pero no la vida entendida como lo hacían los clásicos griegos, sino como zòe que es introducida violentamente en la ciudad, lo que aparece, a un mismo tiempo, es el dispositivo que la maquinaria estatal moderna pone en funcionamiento a partir de la lógica de la exclusión-inclusiva, es decir, de la disponibilidad de toda vida a ser convertida en nuda vida. Como bien lo destaca Agamben, el nazismo y el fascismo no han sido otra cosa que la radicalización de esta matriz fundacional de la política en la modernidad. El desafío de nuestra época es pensar a fondo esta paradoja. Por eso para Agamben, siguiendo en esto a la Escuela de Frankfurt, hay una íntima aunque negada relación entre democracia y totalitarismo, lo que vuelve indispensable profundizar en el sentido de esta relación, teniendo en cuenta la realidad de una época, la nuestra, en la que la democracia se levanta como el Gran Orden político, el que hegemoniza todo discurso y el que determina el sentido de la vida en su totalidad.

Pero para profundizar en la transformación que la figura del Homo Sacer ha sufrido en la modernidad, Agamben recurre a otra categoría fundamental, la de estado de excepción que la piensa apelando, sobre todo aunque en una perspectiva crítica, a Carl Schmitt y a Walter Benjamin. Sin embargo su objetivo es destacar la profunda imbricación entre construcción del poder soberano, estado de excepción y violencia exterminadora. El encabezado de esta parte del libro será la famosa frase del jurista alemán: "Soberano es el que decide sobre el estado de excepción”. A partir de esta definición surge una de las paradojas más significativas de la construcción de la soberanía en la modernidad: "El soberano está, al mismo tiempo, fuera y dentro del ordenamiento jurídico". Agamben, siguiendo a Schmitt, precisa aún más esta afirmación: "Si el soberano es, en efecto, aquél a quien el orden jurídico reconoce el poder de proclamar el estado de excepción y de suspender, de este modo, la validez del orden jurídico mismo, entonces 'cae, pues, fuera del orden jurídico normalmente vigente sin dejar por ello de pertenecer a él, puesto que tiene competencia para decidir si la constitución puede ser suspendida in toto" "18. El soberano puede situarse fuera de la ley ya que tiene el atributo de suspenderla, surgiendo una nueva paradoja al estar la ley fuera de sí misma: "Yo, el soberano, que estoy fuera de la ley, declaro que no hay un afuera de la ley". El orden nacionalsocialista partió de esta premisa, hizo del führer aquel sujeto excepcional que fundaba la ley y permanecía fuera de ella sin que eso significara ninguna contradicción en los términos. "La ley es el führer" proclamó sin embagues

\footnotetext{
17 G. Agamben, op. cit., p. 20.

18 G. Agamben, op. cit., p. 37.
} 
Carl Schmitt, destacando la excepcionalidad del nuevo ordenamiento político que se había inaugurado en Alemania a partir del ascenso de Hitler al poder. De todos modos, lo que busca mostrar Agamben no es la relación entre el nacionalsocialismo, el estado de excepción, y el papel del führer, su preocupación apunta a desencubrir la genealogía del poder soberano independientemente de su "desvío" fascista o totalitario. Hay en la constitución de la soberanía moderna un acto fundacional que hace del soberano aquél que siendo la ley se pone fuera de ella, y ese momento es lo que denomina el estado de excepción. "No es la excepción la que se sustrae a la regla, sino que es la regla la que, suspendiéndose, da lugar a la excepción, y, sólo de este modo, se constituye como regla, manteniéndose en relación con aquella" ${ }^{19}$. Agamben llama relación de excepción a esta forma extrema de la relación que sólo incluye algo a través de su exclusión, siendo éste el mecanismo que funda la ley en el Estado moderno. El dominio sobre el "afuera", sobre la figura de la exclusión, constituye uno de los resortes principales, el modus operandi, del poder soberano que funda derecho sin tener que atenerse a él. Ese "ocupar el afuera" ha dado lugar a las formas más agresivas del expansionismo externo e interno de los estados modernos.

"Una de las tesis de la presente investigación es precisamente que el estado de excepción, como estructura política fundamental, ocupa cada vez más el primer plano en nuestro tiempo y tiende, en último término, a convertirse en la regla. Cuando nuestro tiempo ha tratado de dar una localización visible permanente a eso ilocalizable, el resultado ha sido el campo de concentración"20. El campo, como espacio absoluto de excepción, es topológicamente diverso de un simple espacio de reclusión. En este sentido, el esfuerzo de Agamben apunta a señalar que el campo de concentración no ha sido un accidente en la marcha del Estado moderno, un accidente ya superado y que se relaciona exclusivamente con el desvío totalitario que representó el nazismo; para el filósofo italiano el estado de excepción está en la base de las políticas concentracionarias, es aquello que surge cuando lo ilocalizable se hace "visible", cuando la exclusión radical, la nuda vida, encuentra un sujeto reducible a la nada concentracionaria. La localización visible de lo ilocalizable (la exclusión) conforma, en nuestro tiempo, la política del exterminio. El derecho, y en esto Agamben sigue a Benjamin, se funda en la violencia (la policía es una de las patas esenciales para la producción de la ley y no su mera custodia) ${ }^{21}$,

${ }^{19}$ G. Agamben, op. cit., p. 31.

${ }^{20}$ G. Agamben, op. cit., p. 33.

${ }^{21}$ Véase de Walter Benjamin el extraordinario ensayo "Para una crítica de la violencia" en el que desarrolla ampliamente la relación entre violencia y derecho ligada a la función policial (en Para una crítica de la violencia y otros ensayos, Taurus, Madrid, 1991, trad. de Roberto Blatt). 
con lo que la exclusión del homo sacer no quiebra la presencia de la ley en el seno de la sociedad (la Alemania nazi siguió rigiéndose por las normas jurídicas mientras desplegaba una política de exterminio que, precisamente, quedaba al margen, fuera de la ley sin por ello contradecir el orden jurídico. De lo que se trataba era de la figura de la exclusión, del homo sacer, de aquel que no recibe la ley porque no puede ser sujeto de ella, sólo objeto de la aniquilación). Es significativo, destaca Agamben, que Foucault no haya pensado la decisiva importancia del campo de concentración como la forma que adquiere, en el siglo veinte, el espacio absoluto de excepción. La perspectiva foucaultiana del poder capilarizado, disperso socialmente y no reducido a una acción destructiva, se choca de frente con la presencia alucinante del campo de concentración, sitio en el que precisamente la terrible "concentración" de poder se funda en la lógica de la excepcionalidad. ¿Por qué Foucault no pudo pensar la dimensión concentracionaria y sí lo hizo con la cárcel o el hospicio? Agamben muestra que "mientras el derecho penitenciario no está fuera del ordenamiento normal, sino que constituye sólo un ámbito particular del derecho penal, la constelación jurídica que preside el campo de concentración es (...) la ley marcial o el estado de sitio"22. Se trata de la anulación de las garantías individuales y de un "más allá" de la ley que, sin embargo, funda las políticas del Estado en nuestro siglo ${ }^{23}$. El caso argentino durante la dictadura militar del general Videla es paradigmático del funcionamiento sin contradicción del orden jurídico y de una red clandestina de campos de concentración que, desde la oscuridad y el secreto, determinaban el verdadero funcionamiento del Estado represor. En la figura del desaparecido reencontramos, sin mediación de ningún tipo, al homo sacer, a la nuda vida en su terrible significación. "La excepción -sostiene Agamben- es lo que no puede ser incluido en el todo al que pertenece y que no puede pertenecer al conjunto en el que está ya siempre incluida"24. El desaparecido adquiere el carácter de esa excepción, de esa negación radical que, sin embargo, permanece silencioso como fundamento de lo incluido. Agamben está señalando que, en última instancia, no hay posibilidad de distinguir aquello que está incluido, en tanto que lo normal, de lo excluido, en tanto que excepción, porque lo primero se funda sobre lo segundo sin poder reco-

22 G. Agamben, op. cit., p. 33.

${ }^{23}$ No sólo en la Alemania hitleriana, sino también los campos de internamiento de poblaciones sospechosas como los japoneses en los Estados Unidos durante la Segunda Guerra o los que implementaron los ingleses en Sudafrica durante la guerra de los bóers. Con estos ejemplos quiero destacar que el campo de concentración no es reducible sólo a la experiencia totalitaria nazi o stalinista, como lo sostiene principalmente $\mathrm{H}$. Arendt en Los orígenes del totalitarismo, aunque en esas terroríficas experiencias alcanzó su máxima dimensión criminal y siempre es oportuno destacar las diferencias para no caer en peligrosas simplificaciones.

${ }^{24}$ G. Agamben, op. cit., p. 39. 
nocerlo. En el régimen totalitario el campo de concentración constituye una excepción que funda la norma, es un afuera que fija las condiciones de existencia del adentro. Su invisibilidad es su potencia. Sería erróneo suponer que esa línea que separaba al campo del resto de la sociedad señalaba la distancia infranqueable entre el primero y la segunda, más bien debe ser pensada como la irradiación invisible pero pertinaz de la horrorosa figura concentracionaria sobre la existencia de la sociedad. No saber nada era un modo de saberlo todo, y eso lo implementó desde un principio el poder, ya sea el de los nazis, el stalinista o el de la dictadura argentina. Allí está pero no lo vemos, o mejor dicho, está sin estar porque ha quedado del lado de afuera de la inclusión marcando a fuego, sin embargo, a los sujetos de la inclusión. Potencialmente el campo se extiende, jamás se contrae, y su extensión puede ser tanto material como imaginaria. Desde esta perspectiva, Auschwitz representa la más terrible manifestación de la lógica concentracionaria desplegada en el siglo veinte.

Siguiendo la lógica de su análisis, Agamben destacará que "el haber pretendido restituir al exterminio de los judíos un aura sacrificial mediante el término 'holocausto' es una irresponsable ceguera historiográfica. El judío bajo el nazismo es el referente negativo privilegiado de la nueva soberanía biopolítica y, como tal, un caso flagrante de homo sacer, en el sentido de una vida a la que se puede dar muerte pero que es insacrificable. El matarlos, no constituye, por eso (...) la ejecución de una pena capital ni un sacrificio, sino tan sólo la actualización de una simple posibilidad de recibir la muerte que es inherente a la condición de judío como tal. La verdad difícil de aceptar para las propias víctimas, pero que, con todo, debemos tener el valor de no cubrir con velos sacrificiales, es que los judíos no fueron exterminados en el transcurso de un delirante y gigantesco holocausto, sino, literalmente, tal como Hitler había anunciado, 'como piojos', es decir como nuda vida. La dimensión en que el exterminio tuvo lugar no es la religión ni el derecho, sino la biopolítica" 25 . El problema de este tipo de argumentaciones surge cuando preguntamos por qué la elección de aquellos que serían homo sacer recayó sobre los judíos, es decir, qué otros componentes, no político-estatales, contribuyeron en la elaboración del radical antisemitismo nacionalsocialista, componentes no reducibles a una biopolítica. Pensado desde otro lugar: el despliegue de una biopolítica se funda en una lógica pragmática y en necesidades de reproducción del Estado, su objetivo no puede ser acelerar su disolución o poner en peligro su seguridad. Ahora bien, a partir de 1943, y claramente desde 1944, cuando la guerra comienza a perderse y los nazis deben volcar todos los esfuerzos a defender sus posiciones, el programa de exterminio no sólo sigue adelante

${ }^{25}$ G. Agamben, op. cit., p. 147. 
sino que se acelera y se distraen recursos esenciales para la maquinaria bélica; esto significa que el antisemitismo era probablemente el eje principal del nazismo, su vitalidad, el sentido de su existencia, y que si para llevar adelante el exterminio de los judíos era necesario despilfarrar recursos vitales para la defensa del país se despilfarrarían. En este punto, la argumentación de Agamben no nos alcanza, su impecable lógica choca contra el absurdo de un proyecto, el nazi, que no deja de comportarse contra los intereses del propio Estado al que fortifica desde otros lugares. La consecución de la política de exterminio al ir en detrimento de los intereses estatales alemanes y de la maquinaria guerrera nos está señalando la enorme dificultad que existe a la hora de operar con ciertos esquemas prefijados sobre las prácticas nazis. Pero también es posible, y creo que a eso apunta en parte la escritura agambediana, ver en la Solución final el núcleo fundamental, la estructura paradigmática, del poder soberano y de su verdadera esencia en la modernidad, allí donde lo que se sostiene de manera radical e intransigente es el dominio absoluto por parte del Estado del cuerpo de sus súbditos. Agamben, que tiene como fondo contemporáneo la tragedia de la ex-Yugoslavia y la reproducción de políticas genocidas, algunas de una abrumadora realidad como en el Africa y otras construidas desde la sutileza de las leyes antiinmigratorias europeas, ve en la experiencia nazi, en su Solución final del problema judío, el eje desde el cual ha seguido manifestándose el poder omnímodo del Estado moderno hasta nuestros días. Vale, en este sentido, una cita que hace de Michel Foucault: "Durante milenios, el hombre siguió siendo lo que era para Aristóteles: un animal viviente capaz, además, de existencia política; el hombre moderno es un animal en cuya política está puesta en entredicho su vida de ser viviente" ${ }^{\text {26 }}$. El nazismo representa el estado más amplificado de esta mutación del hombre político aristotélico al ser viviente cuya vida no le pertenece. El judío sería la metáfora de lo que puede acontecerle a todos aquellos que, por diversos motivos, pasan a ser homo sacer, y Agamben ve huellas, en la sociedad actual, que llevan hacia esa dirección. "Sólo porque en nuestro tiempo la política ha pasado a ser íntegramente biopolítica, se ha podido constituir en una medida desconocida, como política totalitaria"27. Agamben le critica a Arendt no haber visto que es la transformación radical de la política en el espacio de la nuda vida la que ha legitimado el dominio total, y no a la inversa como lo sostenía la autora de La condición humana.

El estilete crítico de Agamben nos ha permitido escrutar desde otro lado el carácter original y específico del exterminio de los judíos llevado a cabo

\footnotetext{
${ }^{26}$ G. Agamben, op. cit., pp. 151-152.

27 G. Agamben, op. cit., p. 152.
} 
por el nazismo; en todo caso, al intentar precisar la especificidad de Auschwitz descubrimos de qué modo se concatenan una serie de factores que, a simple vista, parecían tener muy poco que ver entre sí. Desde ese lugar que el judío ocupará en la historia de Occidente, especialmente a partir del gesto cristiano, hasta la ominosa figura del Homo Sacer que vehiculiza el dominio, en la configuración del Estado moderno, de la biopolítica, lo que aparece con especial intensidad es que aquello que lleva el nombre maldito de Auschwitz representa, en grado sumo, la barbarie como núcleo de la racionalidad occidental. En la estela dejada por el universo concentracionario deberemos afrontar la imperiosa tarea de revisar a fondo aquellos legados que hicieron posible, más allá de sí mismos, el despliegue del mal en un tiempo histórico, el nuestro, que se había prometido la realización de la felicidad y el bienestar para los seres humanos. La sombra del horror sigue dibujando su silueta en nuestro presente recordándonos que el destino de los judíos en Auschwitz hace literalmente imposible cualquier ingenuidad y cualquier desplazamiento de nuestras responsabilidades.

En la trama de Occidente hemos podido vislumbrar, desde los lejanos comienzos del cristianismo paulino hasta la construcción del Estado soberano que hará el giro, como señala Agamben, hacia la biopolítica, de qué modo el exterminio de los judíos europeos significó el punto de inflexión, ese instante fatídico en el que cristalizó un itinerario cargado de exclusión, odio y negación del otro. Experiencia límite que contaminó, hacia atrás y hacia adelante, la travesía civilizatoria de nuestra cultura dejándole una marca indeleble que exige, aún hoy, su continua interrogación. Por eso hablar de la especificidad de Auschwitz, pronunciar ese nombre maldito, no significa leer, en el archivo del museo de la memoria, las fojas de un expediente definitivamente clausurado en la historia de la humanidad, sino que significa volver, una y otra vez, a confrontarnos con la permanencia del mal en nosotros, en nuestra sociedad, en nuestro lenguaje y, también, en el gesto de nuestras negaciones. Ya que más allá de la crisis que desde Mallarmé en adelante destituyó el contrato entre palabra y mundo, aquello que verdaderamente inauguró el tiempo del no saber y del no poder decir, fue Auschwitz. Punto límite, silencio del verbo ante la barbarie absoluta que, con la prolijidad de un relojero maldito, desplegó las fuerzas destructivas desde el seno de esa misma lógica de la representación que había echado las bases, en el origen de la modernidad y de su sujeto, de la vía regia de la objetualización de seres humanos y naturaleza. Auschwitz hace estallar el sentido, no porque éste no se haya cumplido en los campos de la muerte, sino precisamente porque el itinerario histórico de la razón moderna no pudo impedir que desde su propio seno emergieran las fuerzas destructivas de lo humano, haciendo del lenguaje del sujeto cómplice de la maldad radical. 
Nosotros nos movemos en el interior de la honda expansiva de una barbarie que dejó al habla racional no sólo sin argumentos emancipatorios sino, más grave aún, la comprometió con su inaudito potencial de horror y destrucción. Después de Auschwitz significa no su lejana colocación en las aventuras trágicas de la humanidad del siglo veinte, sino su insolente pertinencia a la hora de intentar pensar los claroscuros de una contemporaneidad atravesada de lado a lado por la irradiación de la barbarie. 